\title{
MODEL KEBIJAKAN DAN PERENCANAAN PENGAWASAN LEMBAGA KEUANGAN MIKRO SYARIAH (STUDI LKMS DI WILAYAH BOGOR)
}

\section{MODEL POLICY AND PLANNING OF MISSING INSTITUTIONS OF MICRO SYARIAH (LKMS STUDY IN REGION BOGOR)}

\author{
R. Trihantana'; A. Alhifni² \\ 1Program Studi Perbankan Syariah Fakultas Ekonomi Islam Universitas Djuanda, Jl. Tol \\ Ciawi No. 1, Kotak Pos 35 Bogor 16720 \\ ${ }^{2}$ Program Studi Perbankan Syariah Fakultas Ekonomi Islam Universitas Djuanda, Jl. Tol \\ Ciawi No. 1, Kotak Pos 35 Bogor 16720
}

\begin{abstract}
The purpose of this research is to create policy model and planning of supervision of sharia micro finance institution in Bogor region. The research method used is qualitative method with miles and huberman analysis technique. The results showed that the LKMS in the Bogor region is generally supervised by the Ministry of Cooperatives, LKMS managers assume that LKMS is more appropriate if supervised by the Ministry of Cooperatives. The proposed policy model and supervisory planning generated in this study are divided into four applied models, the first OJKM supervisory model (microfinance service authority) that is making LKMS special supervisory institutions, both OJK supervisory models (LKMS supervision supervision) OJK, the three supervisory models of the Ministry of Cooperatives, namely LKMS supervision, are fully supervised by the Ministry of Cooperatives, the four joint supervisory models of the Ministry of Cooperative and OJK patnership, cooperative supervision is done by the Ministry of Cooperatives while the supervision of LKMS's financial management is supervised by $0 \mathrm{JK}$.
\end{abstract}

Keywords: Policy, Planning, Supervision, Micro Sharia Financial Institution 


\section{ABSTRAK}

Tujuan penelitian ini untuk membuat model kebijakan dan perencanaan pengawasan lembaga keuangan mikro syariah diwilayah Bogor. Metode penelitian yang digunakan adalah metode kualitatif dengan teknik analisis miles and huberman. Hasil penelitian menunjukkan bahwa LKMS diwilayah Bogor secara umum diawasi oleh Kementerian Koperasi, pengelola LKMS beranggapan bahwa LKMS lebih tepat jika diawasi oleh Kementerian Koperasi. Adapun usulan model kebijakan dan perencanaan pengawasan yang dihasilkan dalam penelitian ini dibagi dalam empat model terapan, pertama model pengawasan 0JKM (otoritas jasa keuangan mikro) yaitu membuat lembaga pengawasan khusus LKMS, kedua model pengawasan OJK (Otoritas Jasa Keuangan) yaitu pengawasan LKMS diawasi sepenuhya oleh OJK, ketiga model pengawasan Kementerian Koperasi yaitu pengawasan LKMS diawasi sepenuhnya oleh Kementerian Koperasi, keempat model pengawasan gabungan patnership Kementerian Koperasi dan 0JK, pengawasan perkoperasian dilakukan Kementerian Koperasi sementara pengawasan manajemen keuangan LKMS diawasi oleh OJK.

Kata Kunci : Kebijakan, Perencanaan, Pengawasan, Lembaga Keuangan Mikro Syariah

Trihantana, Rully dan Anas Alhifni. 2017. Model Kebijakan dan Perencanaan Pengawasan

$\begin{array}{lllllll}\text { Lembaga Keuangan Mikro Syariah. Jurnal Syarikah } 3 & \text { (2): } 450 \text { - }\end{array}$

\section{PENDAHULUAN}

Indonesia menjadi satu-satunya negara yang paling banyak memiliki Lembaga Keuangan Mikro dan memiliki banyak keunikan yang tidak dimiliki negara lain, salah satu keunikan tersebut LKM di Indonesia memiliki dua lembaga pengawas yaitu Kementrian Koperasi dan Otoritas Jasa Keuangan. Umumnya Lembaga keuangan mikro di Indonesia memiliki dua bentuk yaitu LKM konvensional dan LKM syariah, khusus untuk LKM konvensional ada yang berbentuk PT dan ada yang berbentuk koperasi, LKM yang diawasi oleh Kementrian Koperasi berbentuk KSP dan KSPPS pada tahun 2005 berjumlah 38083 (Kementrian Koperasi, 2017) sementara LKM syariah di pulau Jawa pada tahun 2016 berjumlah 2141 (Alhifni et al, 2017). Pada mulanya semua LKM hanya diawasi oleh Kementrian Koperasi dan saat ini sudah mulai diawasi oleh 0JK (Otoritas Jasa Keuangan). Mulai berdirinya OJK pada tahun 2013 sebagai lembaga pengawas jasa-jasa keuangan (termasuk lembaga keuangan mikro syariah) memiliki kebanggaan tersendiri dan menumbuhkan optimisme kepercayaan masyarakat terhadap pengelolaan lembaga yang prudential. Namun sangat disayangkan, sampai akhir tahun 2015 OJK belum bisa mengawasai secara optimal seluruh jasa keuangan yang ada khususnya lembaga keuangan mikro syariah, saat ini LKM yang diawasi oleh 0JK sampai pada akhir April 2017 hanya 160 LKM termasuk LKMS (OJK, 2017).

Ada banyak faktor yang menyebabkan ketidaksiapan lembaga keuangan mikro untuk mematuhi setiap aturan yang diberlakukan OJK sehingga berdampak pada jumlah LKMS yang diawasi OJK. Ketidaksiapan tersebut disebabkan para pengelola LKMS yang menganggap bahwa kebijakan dan perencanaan pengawasan yang dilakukan OJK kurang sesuai dengan kondisi yang ada di lembaga keuangan mikro, kebijakan dan perencanaan pengawasan yang diberlakukan OJK dinilai hanya cocok untuk lembaga keuangan Bank, oleh karena itu pemberlakuan 
terhadap LKMS harus dilakukan dengan mempertimbangkan kondisi dan karakteristik LKMS. Walaupun kebijakan dan perencanaan pengawasan yang dilakukan OJK memiliki tujuan yang baik, namun bukan tidak mungkin jika pemberlakuannya disamakan dengan lembaga keuangan Bank, maka lembaga keuangan mikro syariah akan mengalami kesulitan untuk mematuhi semua aturan tersebut dan akan berdampak pada perkembangan lembaga keuangan mikro syariah di Indonesia yang selama ini berada di jantung nadi perekonomian Indonesia. Berdasarkan latar belakang tersebut perlu kiranya dilihat bagaimana persepsi pengelola LKMS terhadap kebijakan dan pengawasan yang ada saat ini, dan bagaimana usulan model kebijakan, perencanaan dan pengawsan Lembaga Keuangan Mikro Syariah.

\section{MATERI DAN METODE}

\section{Teori Pengawasan}

Menurut R.Tery (2006) mengartikan pengawasan sebagai mendeterminasi apa yang telah dilaksanakan, maksudnya mengevaluasi prestasi kerja dan apabila perlu, menerapkan tindakan-tindakan korektif sehingga hasil pekerjaan sesuai dengan rencana yang telah ditetapkan. Sedangkan Terry (dalam Sujamto) menyatakan bahwa pengawasan adalah untuk menentukan apa yang telah dicapai, mengadakan evaluasi atasannya, dan mengambil tindakan-tindakan korektif bila diperlukan untuk menjamin agar hasilnya sesuai dengan rencana. Dale dalam Winardi, 2000 mengatakan bahwa pengawasan tidak hanya melihat sesuatu dengan seksama dan melaporkan hasil kegiatan mengawasi, tetapi juga mengandung arti memperbaiki dan meluruskannya sehingga mencapai tujuan yang sesuai dengan apa yang direncanakan.

Pada awal tahun 2013 DPR telah mengesahkan UUD no. 1 tentang lembaga keuangan mikro terkait pembinaan, pengaturan dan pengawasan dalam aturan tersebut juga dibedakan antara lembaga keuangan mikro konvensional dan lembaga keuangan mikro syariah dan diatur juga tentang aturan payung hukum lembaga keuangan mikro sebagai lembaga koperasi atau perseroan terbatas, hal ini juga diperkuat dengan adanya Peraturan otoritas jasa keuangan Nomor 14 /pOJK $.05 / 2014$ Tentang Pembinaan dan pengawasan Lembaga keuangan mikro, pada peraturan tersebut dijelaskan bahwa dalam melakukan pembinaan OJK melakukan kordinasi dengan kementrian terkait seperti kementrian koperasi dan kementrian dalam negeri. Dalam rangka melaksanakan pengawasan OJK melakukan pemerikasaan terhadap LKM (OJK , 2015). Adanya peraturan tersebut dapat memberikan angin segar khususnya bagi lembaga keuangan mikro syariah untuk terus melebarkan sayapnya, adanya OJK sebagai lembaga otoritas jasa keuangan dianggap sudah tepat, kewenangan dan pengawasan OJK pada perbankan diharapkan dapat bersinergi dengan lembaga keuangan mikro, sinergi ini penting untuk mengawasi seluruh transaksi keuangan baik di perbankan maupun LKM, namun tentunya bentuk sinergi tersebut tidak semerta-merta bisa menyamakan pemberlakuan aturan dari kedua lembaga keuangan tersebut, karena masing-masing punya ciri-ciri yang berbeda-beda dan risiko berbeda, disinilah perlu adanya formula khusus untuk dibuat sebuah aturan kebijakan dan perencanaan lembaga otoritas jasa keuangan dalam mengawasi setiap lembaga keuangan 
mikro. Selain itu ada hambatan lain yang membuat OJK belum bisa merangkul semua LKM sampai saat ini salah satu hambatannya adalah jumlah lembaga keuangan mikro yang sangat banyak dan bervariatif memberikan kesulitan pada OJK untuk membuat aturan yang tepat khususnya dalam menjalankan kewenangannya dalam melakukan pembinaan dan pengawasan pada lembaga keuangan tersebut hal ini dikarenakan sampai saat ini OJK belum memiliki SDM yang cukup (Baskara, 2013).

\section{Lembaga Keuangan Mikro Syariah}

Lembaga Keuangan Mikro Syariah (LKMS), BMT atau KJKS adalah balai usaha mandiri terpadu yang mengembangkan usaha-usaha produktif dan investasi untuk meningkatkan kualitas kegiatan ekonomi, atau dapat disebut sebagai lembaga yang menyediakan jasa penyimpanan, pembiayaan, dan jasa pembayaran berbagai transaksi jasa yang ditujukan bagi masyarakat menengah dan bawah dan pengusaha kecil atas dasar tolong menolong dan dikelola berdasarkan prinsip-prinsip syariah (Salidin, 2000). Lembaga keuangan bank adalah bank komersil, sedangkan lembaga keuangan non bank adalah seperti LKMS, KJKS atau BMT. Lembaga Keuangan Mikro Syariah (Syariah Financial Institution) merupakan suatu badan usaha atau institusi yang memiliki kekayaan terutama dalam bentuk aset-aset keuangan (Financial assets maupun non financial assets) atau aset riil yang dioperasikan sesuai dengan prinsip syariah lembaga ini juga bisa disebut dengan BMT Baitul Mal Wat Tamwil (Romdoni, 2008; Sudarsono, 2003). Konsep utama dari Lembaga Keuangan Syariah atau BMT adalah melakukan pembinaan dan pendanaan yang sesuai dengan prinsip syariah dalam semua kegiatan ekonominya khususnya dalam mendukung kegiatan ekonomi masyarakat. Adapun fungsi yang harus dijalankan oleh LKMS atau BMT menurut Huda dan Heykal (2013) adalah sebagai berikut :

a. Penghimpunan dan penyaluran dana dengan menyimpan uang di LKMS atau BMT, uang tersebut dapat ditingkatkan utilitasnya, sehingga timbul unit surplus.

b. Pencipta dan pemberi likuiditas, dapat menciptakan alat pembayaran yang sah yang mampu memberikan kemampuan untuk memenuhi kewajiban suatu lembaga atau perorangan.

c. Sumber pendapatan LKMS atau BMT dapat menciptakan lapangan kerja baru dan dapat memberikan pendapatan pada pegawainya secara proporsional.

d. Pemberi informasi, memberikan informasi secara jelas kepada masyarakat mengenai risiko, keuntungan, dan peluang-peluang yang ada di lembaga keuangan tersebut.

e. Sebagai LKMS atau BMT dapat memberikan pembiayaan bagi masyarakat dan UKM dengan tidak memberatkan dalam pemberlakuan jaminan yang disyaratkan.

f. Meningkatkan kualitas SDM anggota, pengurus, dan pengelola untuk lebih profesional, salam (selamat, damai dan sejahtera) dan amanah sehingga dapat lebih utuh dan tangguh dalam berjuang menghadapi tantangan global saat ini.

g. Mengorganisasi dan memobilisasi sehingga dana yang dimiliki oleh masyarakat dapat dimanfaatkan secara optimal didalam dan diluar organisasi untuk kepentingan rakyat banyak.

h. Mengembangkan kesempatan kerja bagi masyarakat.

i. Mengukuhkan dan meningkatkan kualitas usaha dan memasarkan produk-produk yang dihasilkan oleh 
para anggota, dan memperkuat dan

meningkatkan kualitas lembaga-

lembaga ekonomi dan sosial

masyarakat.

Nasariah (2014) dengan judul Pengawasan Lembaga Keuangan Mikro Oleh Otoritas Jasa Keuangan (Analisis Terhadap Undang-Undang Nomor 1 tahun 2013). Hasil Penelitiannya menunjukkan bahwa Undang-Undang Nomor 1 Tahun 2013 dilakukan oleh Otoritas Jasa Keuangan yang melakukan koordinasi dengan kementerian yang menyelenggarakan urusan koperasi dan Kementerian Dalam Negeri. Tetapi dalam hal pembinaan dan pengawasan tersebut Otoritas Jasa Keuangan tidak bekerja sendiri melainkan mendelegasikan wewenangnya kepada Pemerintah Daerah Kabupaten/Kota agar menjalankan wewenangnya tersebut dan tetap dalam pengawasan Otoritas Jasa Keuangan.

\section{Metode Penelitian}

Metode penelitian yang digunakan adalah metode penelitian kualitatif, teknik pengumpulan data menggunakan wawancara dan observasi pada pengelola LKMS dari 10 LKMS yang ada diwilayah Bogor dan Otoritas pengawas (Dinas Koperasi), hasil wawancara dan observasi tersebut kemudian dianalisis menggunakan teknik analisis data Miles dan Huberman. Teknik analisis data menggunakan teknik analisis Miles \& Huberman analisis data yang dilakukan dengan cara reduction, display, dan conclusion drawing sebagaimana tergambar pada gambar 1 (Sugiyono, 2011 ; Creswell, 1998 ; Creswell, 2010 ; Moleong, L.J. (2012). 


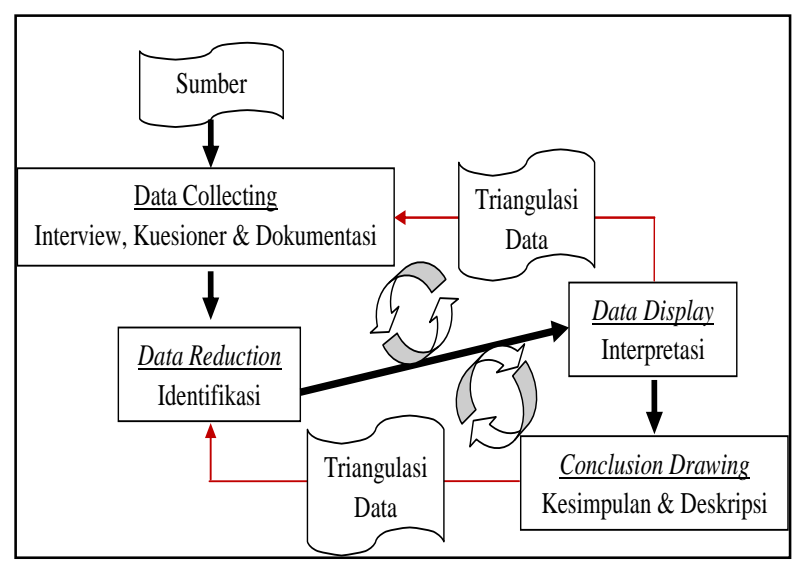

Gambar 1. Modifikasi Model Miles dan Huberman

Sementara untuk menghasilkan model perencanaan pengawasan LKMS diwilayah Bogor peneliti menggunakan teknik pengumpulan data menggunakan (Focus Group Discussion) FGD, dengan lembaga pengawas LKMS diwilayah Bogor (Dinas Koperasi: Ali, SP), perwakilan pengelola LKMS diwilayah Bogor (Luth Ferdian, SE, Abdul Rozak, SEI, Asep Aris Nurjaman, SEI), Ahli dibidang hukum (Rifqy Thantawi, SH.,M.Si), Ahli dibidang Muamalah (H. Qomaruddin,S, Sofian Muhlisin, LLB.,LLM).

LKMS yang menjadi objek penelitian sebanyak 10 LKMS yang berada di wilayah Bogor:

1. BMT Mu'allimin

2. KSPPS Khairu Ummah

3. KSPPS Wihdatul Ummah

4. KSPPS Khidmatul Ummah

5. KSPPS Berkah Mandiri Sejahtera

6. KSPPS Tadbirul Ummah

7. KSPPS Baitul Ikhtiyar

8. BMT Miftahul Huda

9. KSPPS EL-Umma

10. KSPPS Binaul Ummah

LKMS tersebut secara rata-rata sudah berdiri sejak 5 tahun yang lalu, dan semuanya berada di wilayah Bogor, baik Kabupaten Bogor dan Kota Bogor. Setelah dilakukan observasi dilapangan semua
LKMS tersebut telah memiliki izin operasional dari Dinas Koperasi, dan tidak ada yang yang memperoleh izin dari OJK, sehingga seluruh kuesioner dan wawancara yang diberikan mempertanyakan mengenai persepsi pengelola terhadap pengawasan Kementerian Koperasi dan pengawasan OJK jika nanti LKMS tersebut pengawasannya berpindah pada OJK.

\section{HASIL DAN PEMBAHASAN}

\section{Respon Pengelola LKMS Terhadap Pengawasan Kementrian Koperasi}

Berdasarkan hasil wawancara peneliti pada pengelola LKMS secara umum dapat dijelaskan bahwa, 10 LKMS yang berada di wilayah Bogor semuanya diawasi oleh Kementerian Koperasi, sehingga persepsi pengelola LKMS lebih setuju jika LKMS di wilayah Bogor tetap diawasi oleh Kementerian Koperasi dan lebih setuju jika LKMS tetap diawasi oleh lembaga yang memberikan izin, karena secara jumlah LKMS yang memperoleh izin dari Kementrian Koperasi memang lebih besar. berikut adalah pandangan umum pengelola LKMS dan analisa peneliti terhadap pengawasan yang telah dilakukan oleh Kementerian Koperasi :

a. Sampai saat ini belum ada panduan operasional LKMS yang diterbitkan oleh Kementerian Koperasi khususnya manajeman operasional LKMS. Menurut peneliti untuk menjaga keberlangsungan LKMS Kementerian Koperasi perlu membuat peraturan operasional khususnya yang berkaitan dengan risiko, seperti risiko kredit, risiko likuditas, risiko opersional dan risiko legalitas. Respon pengelola pada pertanyaan yang diberikan menunjukkan bahwa pengelola LKMS 
sangat setuju jika hal tersebut diberlakukan dan disesuaikan dengan kondisi LKMS, sehingga kesehatan keuangan LKMS dapat dikontrol dengan baik.

b. Pembinaan yang dilakukan tidak dilakukan secara berkala, dan tidak semua LKMS mendapatkan pembinaan dari Kementrian Koperasi, hal ini dikarenakan SDM Kementrian Koperasi hanya memahami mengenai perkoperasian dan kurang memahami keuangan syariah. Menurut peneliti pengawasan yang dilakukan Kementerian Koperasi saat ini belum optimal khususnya dalam melakukan pembinaan pada LKMS, khususnya pembinaan dari segi syariah dan manajemen keuangan. Strategi yang dapat dilakukan salah satunya dengan bekerjasama dengan Perguruan Tinggi yang memiliki Program Studi Ekonomi dan Keuangan Syariah, baik dalam bentuk pelatihan, bimbingan dan pengawasan.

Secara umum laporan yang diminta Kementerian Koperasi pada LKMS umumnya hanya disampaikan satu tahun sekali setelah pelaksanaan RAT, menurut peneliti hal ini perlu diperbaiki, laporan dapat diberlakukan secara berkala (harian, mingguan, bulanan dan tahunan) dengan menerapkan sistem berbasis online, sehingga perkembangan LKMS dapat diketahui dengan jelas dan dapat menjaga keberlangsungan usaha LKMS.

\section{Respon Pengelola LKMS Terhadap} Pengawasan Otoritas Jasa Keuangan

Sementara pandangan umum pengelola LKMS terhadap pengawasan Otoritas Jasa Keuangan adalah sebagai berikut :

a. LKMS di wilayah Bogor belum ada yang diawasi oleh OJK, sehingga persepsi pengelola LKMS beranggapan bahwa
LKMS tidak akan mampu jika LKMS diawasi oleh OJK karena penerapan peraturannya terlalu berat dan lebih tepat untuk lembaga keuangan bank. Berdasarkan hasil penelitian hal ini perlu dilakukan penyesuaian model pengawasan dan kebijakan LKMS yang lebih sesuai sehingga tidak ada tumpang tindih antara satu lembaga pengawas dengan yang lain dan tidak menimbulkan kebingungan bagi pengelola LKMS.

b. LKMS di wilayah Bogor tidak keberatan jika di awasi oleh OJK, dengan syarat peraturan yang diberlakukan disesuaikan dengan kondisi LKMS, karena pengelola LKMS beranggapan bahwa ketika LKMS diawasi OJK akan dapat menaikkan reputasi LKMS di masyarakat, sehingga lebih banyak masyarakat yang dapat memanfaatkan keberadaan LKMS.

\section{Model Pengawasan LKMS di Wilayah Bogor}

Pengawasan LKMS di wilayah Bogor yang berbadan hukum Koperasi, pengawasannya dilakukan dengan dua model yakni pengawasan internal dan pengawasan eksternal. Pengawasan internal dilakukan oleh dua lembaga pengawas yakni dewan pengawas dan Dewan Pengawas Syariah (DPS). Sementara pengawasan eksternal dilakukan oleh instansi pemerintahan terkait yaitu Kementrian Koperasi. Secara Jelas dapat dijelaskan sebagaimana berikut : 


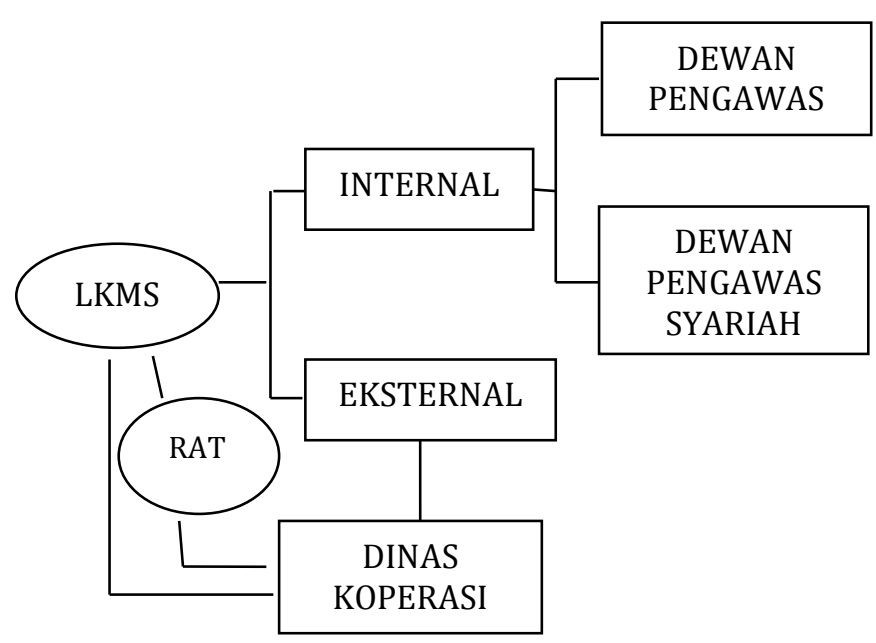

Gambar 2

Model Pengawasan LKMS di Wilayah Bogor

\section{Model Kebijakan dan Perencanaan Pengawasan LKMS}

LKMS adalah lembaga keuangan mikro syariah yang sangat unik, keberadaan LKMS di Indonesia walaupun relatif lebih baru dibanding LKM namun perkembangannya sudah sangat pesat. LKM yang diawasi oleh Kementrian Koperasi berbentuk KSP dan KSPPS pada tahun 2005 berjumlah 38083 (Kementrian Koperasi, 2017) sementara LKM syariah di pulau Jawa pada tahun 2016 berjumlah 2141 (Alhifni et al, 2017). Pesatnya pertumbuhan LKMS memberikan harapan yang sangat besar namun juga menjadi tantangan tersendiri jika tidak dikelola dengan baik, salah satu strategi untuk menjaga keberlangsung LKMS di Indonesia salah satunya dengan membuat model kebijakan dan perencanaan pengawasan yang tepat. Secara kebijakan pemerintah Indonesia saat ini mulai ingin menertibkan penamaan LKMS, salah satunya dengan terbitnya UUD Nomor 1 Tahun 2013 Tentang Lembaga Keuangan Mikro yang diawasi oleh OJK dimana pada pasal 5 disebutkan bahwa badan hukum LKM Koperasi atau Perseroan terbatas, sistem pengawasan yang diterapakn oleh OJK tidak jauh berbeda dengan sistem pengawasan yang diterapkan pada lembaga keuangan bank, sebagaimana tergambar pada pasal 30 dijelaskan bahwa LKM wajib menyampaikan laporan keuangan setiap empat bulan dan laporan administratif sesuai yang ditetapkan OJK.

Sementara LKMS yang diawasi oleh Kementerian Koperasi juga mulai dibenahi dengan menerbitkan peraturan Menkop Nomor 16 Tahun 2015, yang menjelaskan bahwa setiap usaha simpan pinjam pembiayaan syariah harus berbentuk KSPPS primer atau skunder, hal ini adalah usaha pemerintah untuk menyeragamkan nama LKMS menjadi KSPPS dan USPPS (koperasi yang berada dibawah pengawasan Kementrian Koperasi). Kedua bentuk kebijakan dan pengawasan tersebut dapat menimbulkan kebingungan dan keresahan bagi pengelola LKMS karena adanya dua lembaga pengawas yang memiliki wewenang mengawasi LKMS. Berdasarkan masalah tersebut peneliti mengusulkan beberapa model kebijakan dan perencanaan pengawasan yang dapat diterapkan sebagai berikut:

\section{Model I}

Pemerintah perlu membuat peraturan perundang undangan untuk menyeragamkan semua nama LKMS, sehingga tidak ada kebingungan baik dikalangan pengelola LKMS dan masyarakat. LKMS yang ada saat ini ada bernama KSPPS, UJKS, KSP, USPPS, KJKS, BMT, walaupun pemerintah sudah melakukan penertiban dengan nama KSPPS, USPPS dan KJKS. Seharusnya penamaan ini cukup satu yaitu KSPPS sehingga KSPPS dapat dengan mudah diterima di masyarakat. Membentuk lembaga pengawas khusus yang mengawasi lembaga keuangan mikro di 
Indonesia, adanya keseragaman penamaan LKMS dapat memudahkan pemerintah dalam melakukan pengawasan. Untuk mengoptimalkan strategi tersebut pemerintah perlu membentuk lembaga pengawas khusus yang mengawasi lembaga keuangan mikro di Indonesia. Skema pengawsannya dapat dijelaskan sebagaimana pada gambar 3 :

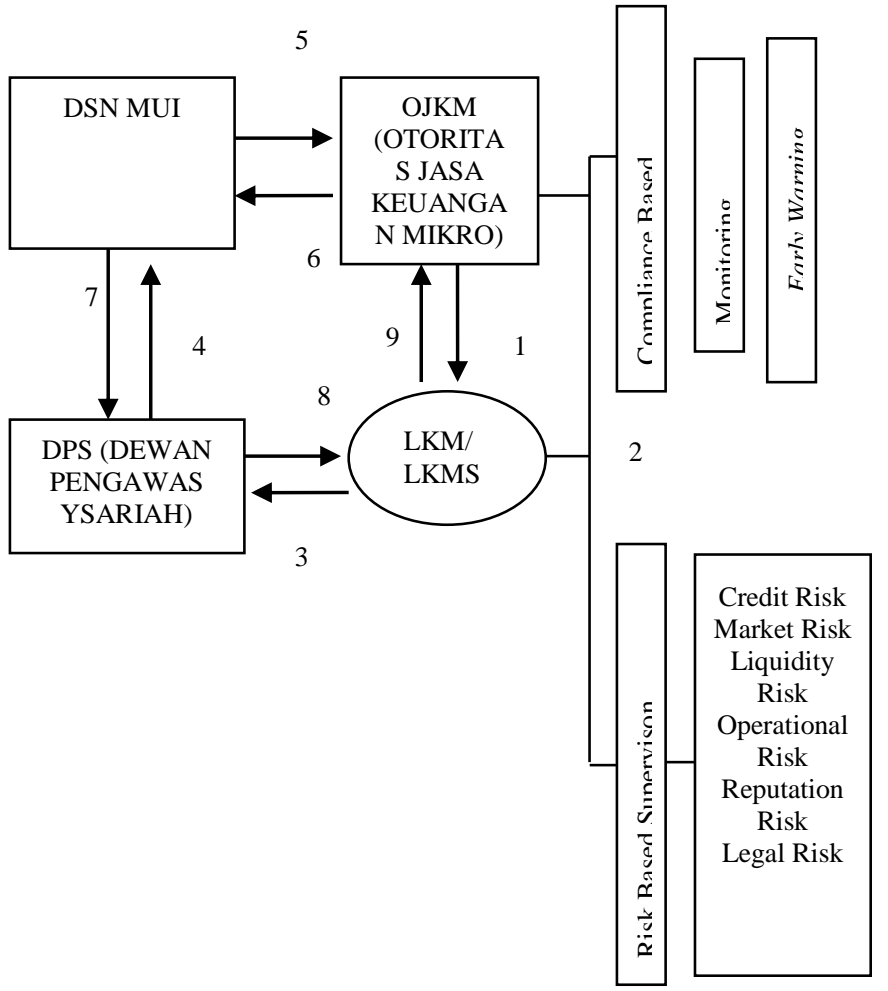

Gambar 3

Model 1 Kebijakan dan Perencanaan Pengawasan LKM/LKMS Oleh OJKM

Penjelasan Gambar :

1. OJKM adalah Otoritas Jasa Keuangan Lembaga Keuangan Mikro yang dapat didirikan secara khusus untuk mengawasi lembaga keuangan mikro di Indonesia.

2. Bentuk pengawasan dan pembinaannya dapat menggunakan dua pendekatan yaitu risk based supervision dan compliance based.

3. LKMS menunjuk dewan pengawas syariah.
4. DPS melakukan koordinasi dengan DSN MUI untuk mendapatkan persetujuan

5. DSN berkoordinasi dengan OJKM atas DPS yang diusulkan oleh LKMS

6. OJKM menyetujui pengajuan DSN MUI

7. DSN MUI mengabulkan pengajuan LKMS dan kemudian dapat dijadikan dewan pengawas syariah yang selalu berkoordinasi dengan DSN dan OJKM.

8. DPS melaporkan kepada LKMS atas persetujuan DSN MUI dan OJKM

9. LKMS selalu memberikan laporan secara berkala pada OJKM dari seluruh kegiatan yang dilakukan LKMS dan setelah mendapatkan persetujuan dari DPS.

\section{Model II}

Terbitnya UUD No. 1 Tahun 2013 tentang lembaga keuangan mikro, pemerintah memberikan kesempatan pada LKM/LKMS untuk diawasi oleh OJK. Keberadaan OJK sebagai lembaga otoritas jasa keuangan di Indonesia dapat dioptimalkan, salah satunya menambah kewenangannya untuk mengawasi LKM/LKMS. Munculnya kewenangan tersebut menambah tupoksi OJK dalam mengawasi LKM khususnya yang dijalankan berdasarkan koperasi dan perseroan terbatas dan hal ini sudah dilakukan OJK mulai tahun 2015 yang lalu. Namun pada perkembangannya banyak LKMS yang mengalami kesulitan dalam mamatuhui sistem pengawasan yang diterapkan OJK, sehingga peneliti mengusulkan model pengawasan dimana semua LKMS harus diawasi oleh OJK sebagai lembaga otoritas keuangan di Indonesia, dan membuat aturan khusus bagi LKM/ LKMS sehingga LKM/LKMS dapat dengan mudah mengikuti semua peraturan yang diterapkan. Adapun model kedua tersebut dapat dijelaskan sebagaimana gambar 4 . 


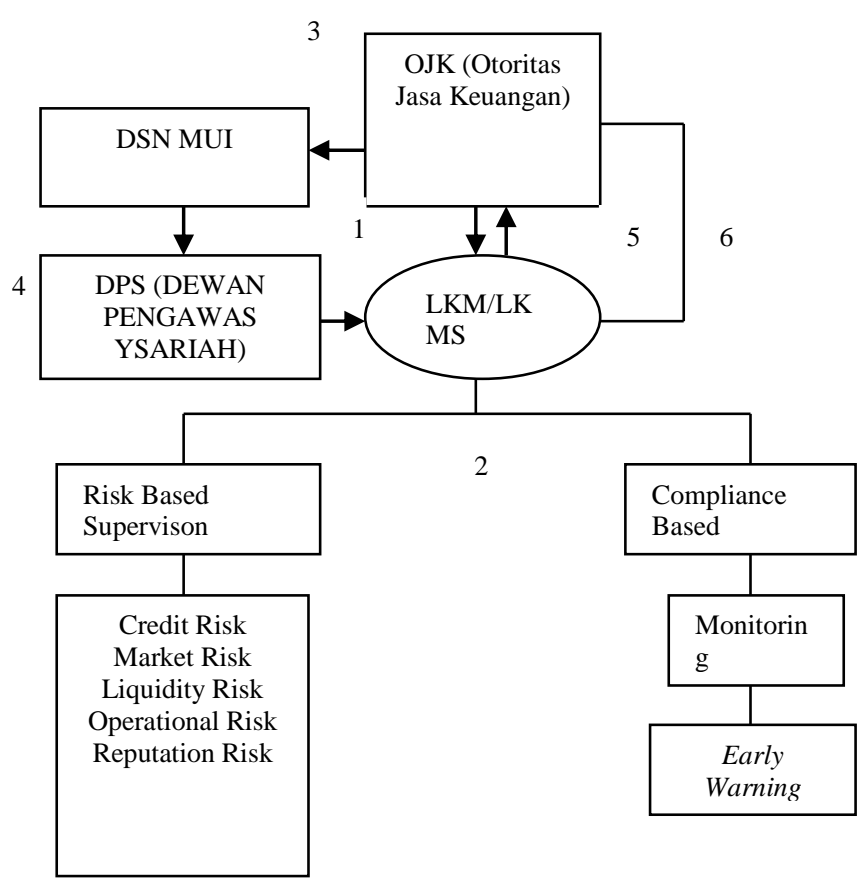

Gambar 4

Model 2 Kebijakan dan Perencanaan Pengawasan LKM/LKMS Oleh OJKM

Penjelasan Gambar

1. OJK sebagai lembaga otoritas mengawasi LKMS

2. OJK mengawasi LKMS dengan dua pendekatan yaitu pendekatan Risk Based Supervison dan Compliance Based.

3. OJK berkoordinasi mengenai DPS pengawas LKMS yang diusulkan

4. DSN menunjuk DPS sebagai pengawas LKMS, dan DPS yang telah ditunjuk langsung berkoordinasi dengan LKMS

5. LKMS melaporkan secara berkala semua kegiatan operasional yang telah dijalankan langsung pada $\mathrm{OJK}$

6. OJK melakukan pembinaan pada LKMS (administrasi, keuangan dan fiqih keuangan)

\section{Model III}

Model ketiga ini adalah model kebijakan dan pengawasan LKMS yang secara menyeluruh dapat diawasi oleh
Kementerian Koperasi, karena jika dilihat dari jenis usaha yang dijalankan, dan sistem operasional yang diterapkan LKMS sama bentuknya dengan koperasi, sehingga lebih tepat jika LKMS diawasi oleh Kementrian Koperasi. Terbitnya peraturan Menkop Nomor 16 Tahun 2015 tentang pelaksanaan kegiatan tentang usaha simpan pinjam dan pembiayaan syariah oleh koperasi, memberikan kesempatan kepada Kementerian Koperasi untuk mengawasi semua lembaga keuangan mikro syariah, walaupun ada beberapa hal yang harus diperbaiki pertama pembinaan, kedua pengawasan. Pada model ini diusulkan beberapa tahapan pembinaan yang dapat dilakukan oleh Kementerian Koperasi seperti pembinaan SDM pengelola, pengurus dan pengawas (perkoperasian, administrasi, keuangan, dam fiqih keuangan) selama ini pembinaan yang diberikan oleh Kementerian Koperasi hanya pada pengelola dan pengurus, sedangkan pengawas internal tidak dilibatkan, pembinaan tersebut dalam bentuk perkoperasian, administrasi dan keuangan, sementara untuk pengetahuan mengenai fiqih keuangan tidak pernah diberikan karena keterbatasan SDM yang ada di Kementerian Koperasi. Pengawasan yang ada saat ini dilakukan dengan dua pendekatan yaitu pengawasan internal dan eksternal (Kementrian Koperasi) dua pendekatan tersebut dinilai tidak optimal pertama karena tidak ada pembinaan yang dilakukan secara kontinu, kedua laporan yang diberikan LKMS pada Kementerian Koperasi tidak dilakukan secara berkala (harian, mingguan atau bulanan), karena hanya disampaikan satu tahun sekali pada saat RAT. Berikut adalah usulan model yang dapat diterapkan pada gambar 5 . 


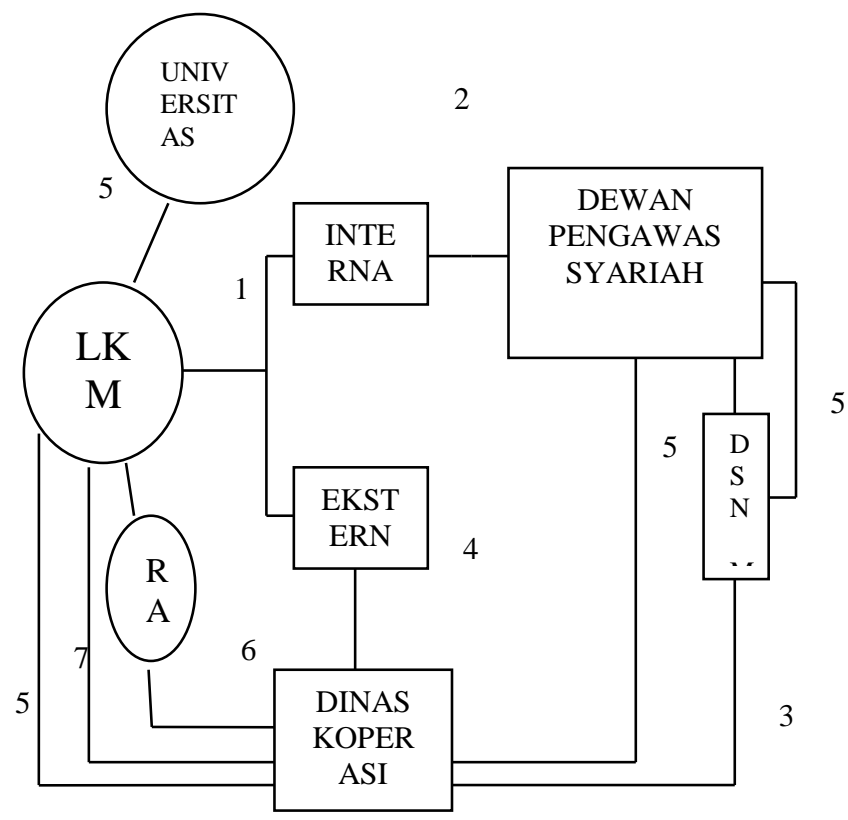

Gambar 5

Model 3 Kebijakan dan Perencanaan Pengawasan LKM/LKMS Oleh OJKM

Penjelasan Gambar

1. LKMS diawasi oleh pengawas internal dan eksternal.

2. Pengawas internal diawasi oleh DPS (Dewan Pengawas Syariah)

3. Dewan pengawas diusulkan oleh LKMS dan disetujui serta dibina oleh DSN MUI dengan berkoordinasi dengan kementerian Koperasi.

4. Pengawasan eksternal LKMS dilakukan oleh Kementerian Koperasi dan dilakukan secara berkala.

5. Dinas koperasi melakukan pembinaan (perkoperasian, administrasi, keuangan, dam fiqih keuangan) pada dewan pengawas koperasi bekerjasama dengan perguruan tinggi dan DSN MUI.

6. LKMS melakukan RAT (Rapat Anggota Tahunan) pada setiap akhir periode sebagai laporan bentuk pertanggung jawaban pada seluruh stakeholders LKMS.

\section{Model IV}

Model keempat ini adalah model kebijakan dan pengawasan yang dapat dilakukan oleh dua lembaga secara bersamaan yaitu OJK dan Kementerian Koperasi, adanya UUD Nomor 1 Tahun 2013 Tentang Lembaga Keuangan Mikro dan Menkop Nomor 16 Tahun 2015 tentang pelaksanaan kegiatan tentang usaha simpan pinjam dan pembiayaan syariah oleh koperasi memungkinkan jika model IV ini diterapkan. Pada model ini Kementerian Koperasi bertindak sebagai otoritas yang mengawasi perkoperasian, sementara OJK bertindak sebagai pengawas keuangannya, sementara untuk pembinaan dilakukan secara bersama oleh kedua otoritas tersebut. Secara jelas mengenai model tersebut dapat dijelaskan melalui gambar 6.



Gambar 6

Model 4 Kebijakan dan Perencanaan Pengawasan LKM/LKMS Oleh OJKM

Penjelasan Gambar

1. LKMS diawasi oleh dua otoritas pengawas yaitu Kementrian Koperasi dan OJK

2. Perkoperasian LKMS diawasi oleh Kementrian Koperasi, bentuk pengawasannya meliputi penentuan 
simpanan pokok, simpanan wajib, simpanan sukarela, kewajiban anggota, pengurus dan pengawas, rapat anggota, rapat pengurus dan RAT.

3. Keuangan LKMS diawasi oleh OJK, bentuk pengawasannya meliputi sistem manajemen keuangan LKMS seperti diberlakukannya GWM (giro wajib minumum) bagi LKMS, pelaporan secara berkala (harian), keberadaan OJK sebagai pengawas keuangan untuk memastikan kesehatan dan transparansi keuangan LKMS.

4. LKMS berkoordinasi dengan DPS untuk memastikan kehalalan setiap transaksi yang dilakukan.

5. Pembinaan pengelola LKMS, pengurus dan DPS dilakukan oleh dua lembaga otoritas yaitu Kementrian Koperasi dan OJK bekerjasama dengan DSN MUI dan Universitas.

\section{KESIMPULAN DAN IMPLIKASI}

\section{Kesimpulan}

Semua LKMS di wilayah Bogor berada dibawah pengawasan Kementerian Koperasi dan tidak ada yang diawasi oleh Otoritas Jasa Keuangan, alasan utama ketidaksiapan LKMS berada dibawah pengawasan OJK karena pengelola LKMS beranggapan bahwa pengawasan yang diterapkan OJK terlalu berat dan lebih tepat jika diterapkan pada lembaga keuangan bank. Para pengelola LKMS memiliki respon yang baik terhadap pengawasan LKMS oleh Kementerian Koperasi, walaupun pengelola LKMS tetap mengakui bahwa pengawasan dan pembinaan yang dilakukan Kementerian Koperasi belum optimal khususnya mengenai manajemen keuangan dan aspek syariahnya. Pengelola LKMS lebih setuju jika LKMS tetap berada dibawah pengawasan Kementerian
Koperasi, pengelola LKMS juga memiliki respon yang baik terhadap Peraturan Menteri mengenai penamaan LKMS sebagai KSPPS. Adapun usulan model kebijakan dan perencanaan pengawasan yang dihasilkan dalam penelitian ini dibagi dalam empat model terapan, pertama model pengawasan OJKM (otoritas jasa keuangan mikro) yaitu membuat lembaga pengawasan khusus LKMS, kedua model pengawasan OJK (otoritas jasa keuangan) yaitu pengawasan LKMS diawasi sepenuhya pada 0JK, ketiga model pengawasan Kementrian Koperasi yaitu pengawasan LKMS diawasi sepenuhnya oleh Kementrian Koperasi, keempat model pengawasan gabungan patnership Kementrian Koperasi dan OJK, pengawasan perkoperasian dilakukan Kementerian Koperasi sementara pengawasan manajemen keuangan LKMS diawasi oleh OJK.

\section{Implikasi}

Berdasarkan hasil penelitian yang telah dilakukan, peneliti menyarankan beberapa hal berikut :

\section{a. Pemerintah}

Perlu dibuat kebijakan yang lebih tegas khususnya mengenai pengawasan dan pembinaan LKMS di Indonesia sehingga keberlangsungan LKMS tetap terjaga. Salah satu bentuk kebijakan yang dapat diambil adalah menerapkan salah satu model pengawasan yang diusulkan peneliti.

b. LKMS

Perlu melakukan perbaikan khususnya dalam manajemen LKMS, salah satunya dengan meningkatkan kemampuan SDM baik kemampuan yang bersifat keuangan dan syariahnya.

c. Kementerian Koperasi

Perlu diperbaiki sistem pengawasan yang telah dilakukan khususnya dalam meningkatkan peran serta Kementerian Koperasi dalam pengawasan dan pembiaan 
LKMS. Salah satunya dengan menambah jumlah SDM yang memiliki kemampuan sesuai dengan yang dibutuhkan

d. OJK

Perlu dibuat peraturan yang lebih sesuai dengan kondisi LKMS di Indonesia sehingga LKMS tidak mengalami kesulitan dalam menjalankan setiap aturan yang diberlakukan.

\section{DAFTAR PUSTAKA}

Alhifni, et al. 2017. Optimization of Coperation Network Between The Government, Private Sectors and Universities in Strengthening SME Capital Through Islamic Finance in Indonesia. Journal Of Arts, Science \& Commerce. ISSN 2231-4172 Vol VIII. Pp.18-27

Baskara, Kajeng, I Gde. 2013. Perkembangan Pemikiran Manajemen Dari Gerakan Pemikiran Scientific Management Hingga Era Modern. Jurnal Manajemen Strategi Bisnis dan Kewirausahaan. Vol.7. No. 2. PP.143151

Buchori. Nur S. 2012. Koperasi Syariah. Jakarta : Aufa Media.

Creswell, John W. 2010. Research Design Pendekatan Kualitatif, Kuantitatif, dan Mixed. Yogyakarta : Pustaka Pelajar.

Creswell, J. W.1998.Qualitative inquiry and research design : choosing among five tradition

London : Sage Publication.

Hasanzadeh, Ali. Meisami, Hossein. 2012. The economic necessity of establishing Islamic microfinance institutes in Iran: A theoretical analysis. Basic Research Journal of Business Management and Accounts ISSN 2315-6899 Vol. 1(1) pp. 06-13.

Huda, Nurul. Heykal, Muhammad, 2013. Lembaga Keuangan Islam, Tinjauan Teoritis dan Praktis. Jakarta : Kencana. Prenada Media Group.

Moleong, L.J. (2012). Metodologi Penelitian Kualitatif Edisi Revisi. Bandung: PT Remaja Rosdakarya.

Nasariah, Naumi. 2014. Pengawasan Lembaga Keuangan Mikro Oleh Otoritas Jasa Keuangan (Analisis Terhadap Undang-Undang Nomor 1 tahun 2013. Skripsi Program Studi Ilmu Hukum Fakultas Syariah dan Hukum UIN Syarif Hidayatullah

R.Terry, George. 2006. Prinsip- Prinsip Manajemen. Jakarta: Bumi Aksara

Romdoni, Ahmad. 2008. Lembaga Keuangan Syariah. Jakarta : Zikrul Hakim.

Salidin, Djaslim. 2000. Konsep Dasar Ekonomi dan Lembaga Keuangan Islam. Bandung : Linda Karya.

Sudarsono, Heri. 2003. Bank dan Lembaga Keuangan Syariah, Deskripsi dan Ilustrasi. Yogyakarta : Ekonisia, Fakultas Ekonomi Universitas Islam Indonesia

Sugiyono. (2012). Memahami Penelitian Kualitatif". Bandung, Alfabeta.

Winardi. 2000. Manajer dan Manajemen. Bandung: Citra Aditya Bakti. www. Kementrian Koperasi.co.id www. Otoritas Jasa Keuangan.co.id 